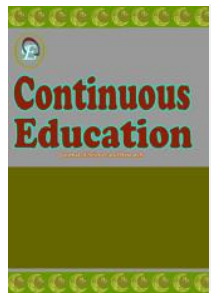

Continuous Education : Journal of Science and Research

Volume 2, Issue 2, July 2021

http://pusdikra-publishing.com/index.php/josr/home-free

\title{
Peranan Ikatan Mahasiswa Kecamatan Batang Kuis Dalam Meningkatkan Kualitas Pendidikan Masyarakat Di Kecamatan Batang Kuis
}

Muhammad Zuhri

Universitas Islam Negeri Sumatera Utara Medan

Corresponding Author: \&uhriku2000@gmail.com

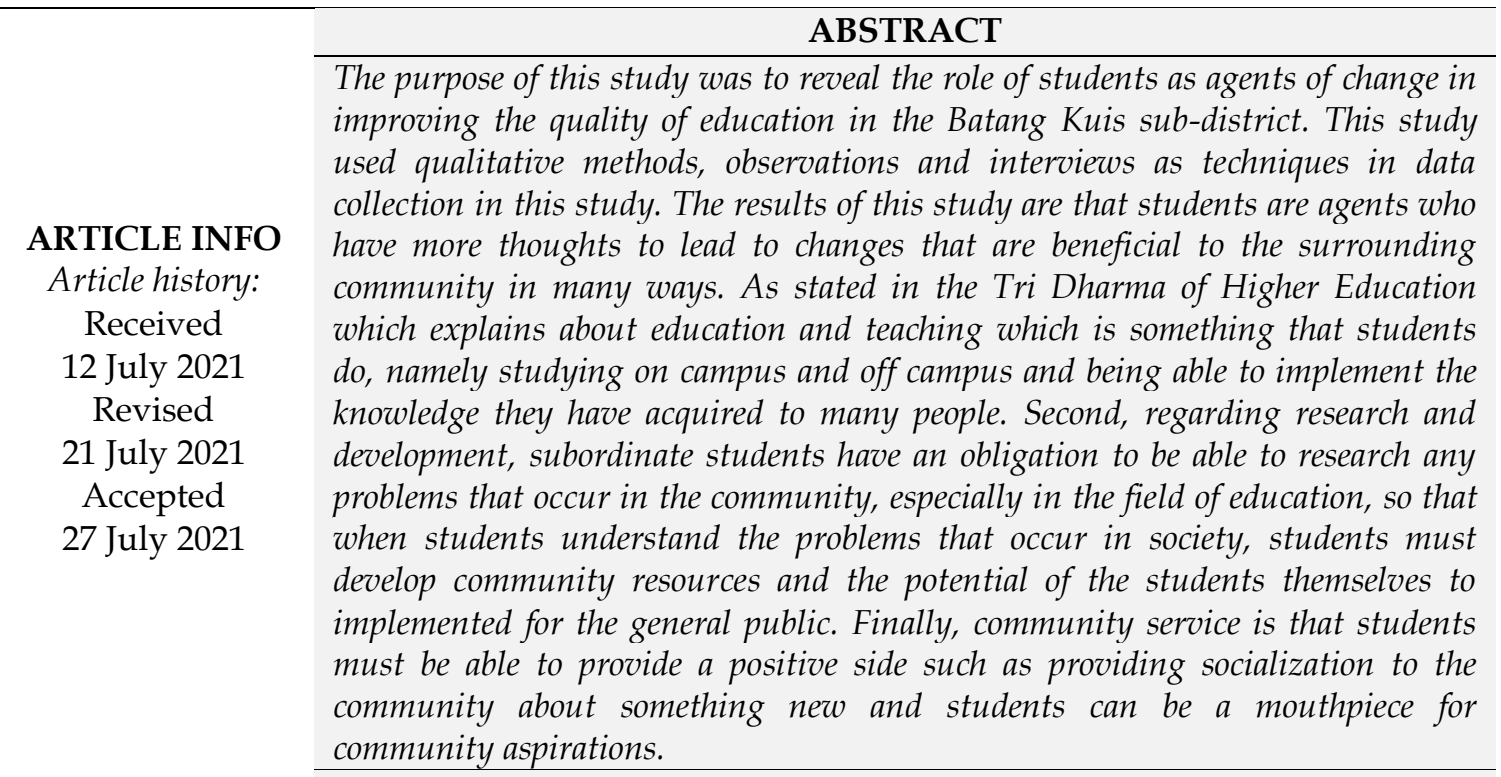

Keywords

Development, Society, Education.

Muhammad Zuhri. (2021). Peranan Ikatan Mahasiswa Kecamatan

Batang Kuis Dalam Meningkatkan Kualitas Pendidikan Masyarakat Di

How to cite

Kecamatan Batang Kuis. Journal Continuous Education, 2(2). 36-45.

$10.51178 /$ ce.v2i2.230.

\section{PENDAHULUAN}

Pendidikan merupaka sarana yang terbaik untuk mendapatkan pengetahuan sejati yang menghantarkan kepada sebab pengetahuan sejati untuk mendapatkan gagasan atau ide yang mengarah kepada perilaku etis tentang nilai-nilai abadi yang tidak patuh pada opini subjek yang sering berubah-ubah (Copleston \& Plato, 2020). Hal ini menandakan setiap golongan tentunya membutuhkan pendidikan untuk menciptakan seuatu yang baru demi kemajuan dari, karena majunya suatu daerah bisa dilihat dari sebesar apa dampak dari pendidikan yang terjadi di daerah tersebut. Pendidikan sebagai wadah untuk menjadikan citra baik bagi masyarakat. Dalam suatu negara 
pendidikan memegang peran yang sangat penting untuk menjamin keberlangsungan hidup suatu bangsa dan negara, karena pendidikan merupakan suatu wadah dalam meningkatkan sumber daya manusia di Indonesia (Zaini \& Syafaruddin, 2020).

Ikatan Mahasiswa Kecamatan Batang Kuis atau disingkat IKMBAKU didirikan pada tanggal 21 Februari 2021, pendiri organisasi ini ialah para mahasiswa yang bertempat tinggal di Batang Kuis yang berkeinginan untuk menggabungkan kelompok Cipayung. Dari hasil pembahasan diskusi yang diadakan oleh kelompok Cipayung Batang Kuis ini maka sepakatlah untuk mendirikan wadah organisasi untuk para mahasiswa yang ada di Batang Kuis yaitu Ikatan Mahasiswa Kecamatan Batang Kuis.

Dengan adanya organisasi yang menyatukan mahasiswa yang ada di Batang Kuis ini tentunya akan berdampak kepada kegiatan-kegiatan yang akan bermanfaat untuk banyak orang. Apalagi mahasiswa dapat menerapkan dan membagi ilmu yang didapatkannya di bangku kuliah supaya orang lain juga dapat mengetahui apa yang belum diketahuinya, hal ini bagus untuk kemajuan daerah dimana terdapat sekumpulan mahasiswa yang mempunyai visi dan misi yang sama untuk memajukan daerah Batang Kuis lebih maju dan baik lagi kedepannya. Fokus kegiatan IKMBAKU dari hasil diskusi bersama anggota Dewan Perwakilan Rakyat Daerah yaitu bapak Saiful Tanjung terdapat tiga point yang menjadi inti pembahasan diskusi mengenai program kegiatan unggulan IKMBAKU yaitu pendidikan, ekonomi dan pemanfaatan sumber daya masyarakat. Dalam tiga point penting progam kegiatan yang akan dilaksanakan saat ini masih sangat fokus untuk kegiatan pendidikan. Hal ini disebabkan masih terdapatnya siswa yang masih menganggap enteng pendidikan dan tentang sekolah daring ini dimana siswa harus belajar dirumah tentunya ini menjadi hambatan siswa untuk mendapatkan ilmu yang lebih.

\section{METODE PENELITIAN}

Penelitian ini menggunakan jenis rancangan metode penelitian kualitatif, yaitu membuktikan fakta-fakta dan kegiatan yang terjadi di lapangan sesuai dengan yang telah diteliti (Darwamawan, 2013). Rancangan penelitian ini tentunya menggunakan variable para siswa dan juga kegiatan yang di lakukan oleh IKMBAKU untuk meningkatkan kualitas pendidikan yang ada di Batang Kuis dengan menggunakan model pembelajaran meningkatkan motivasi dan minta bakat beserta menggunakan teknologi digital untuk mempermudah dalam pembelaran yang sedang berlangsung. Adapun untuk teknik pengumpulan data yaitu dengan Observasi, Oberservasi adalah melakukan pengamatan terhadap muatan ataupun objey penelitian yang dilakukan secara 
langsung ataupun tidak langsung, dalam hal ini peneliti melalukan observasi langsung ialah ketika melakukan program kerja yang dimiliki oleh divisi Pendidikan dan Kesehatan IKMABAKU seperti mengunjungi dinas pendidikan Batang Kuis, wawancara dengan guru-guru dan langsung berinteraksi dengan siswa-siswa yang ada. Sedangkan secara tidak langsung ialah berdiskusi dengan pengurus IKMBAKU mulai dari divisi Pendidikan dan Kesehatan dan Pemanfaatan Sumber Daya Masyarakat, hal ini dilakukan untuk melihat dari kinerja IKMABAKU sekaligus efektivitas yang dilakukan untuk bisa meningkatkan pendidikan yang ada di Batang Kuis. Pemanfaatan buku digital juga menjadi objek yang signifikan disebabkan IKMABAKU menggunakan terobosan baru dalam megembangkan pendidikan yaiu dengan menggunakan pojoj literasi digital yang berupa berpustakaan online, metode pembelajaran online dan audio visual yang dapat di tampilkan. Dengan menggunakan datadata dari hasil wawancara yang langsung tentunya semua akan digabungkan menjadi satu dan juga pertinggal untuk IKMABAKU supaya ada peningkatan. Selanjutnya dilakukan wawancara untuk memperjelas data pengambilan data (Sugiyono, 2016).

\section{HASIL PENELITIAN DAN PEMBAHASAN}

\section{Konsep Pendidikan dan Pengajaran Di Batang Kuis Era Pandemi}

Setiap daerah tentunya memiliki karakterisitik dan konsep pendidikan yang berbeda-beda termasuk di Batang Kuis. Hal ini terjadi karena sistem masyarakat dan juga pengaruh yang ditimbulkan dari hasil pembelajaran yang mengarah pada situasi tempat tinggal, hal ini terjadi di Batang Kuis dimana para siswa bisa untuk fokus belajar dan meyempatkan dirinya untuk berbaur/bermain bersama teman-temannya.

Dalam suasana pembelajaran daring ini konsep pendidikan ataupun pembelajaran disamakan semuanya antara sekolah, sebab dalam keadaan daring yang dapat dimanfaatkan ialah sarana teknologi. Namun apa daya banyak murid yang tidak mempunyai smartphone maka murid tersebut tidak dapat mengakses internet ataupun pembelajaran menjadi terhambat dan merupakan dampak negarif daripada belajar daring. Dinas pendidikan Batang Kuis mengupayakan optimaliasi pendidikan pada masa pandemi pada masa awal pandemi para guru di harapkan memeberikan arahan soal-soal dan membaca buku kepada murid-murid tetapi hal ini tidak efektik, lalu menggunakan cara dimana anak murid disekolah datang bergantian di waktu yang berbeda untuk diberikan arahan maupun tugas namun, hal ini juga di nilai tidak efektif. Dan akhirnnya ada perubahan baru pada jenjang Sekolah Dasar (SD) dan Sekolah Menengah Pertama (SMP) dengan cara sekolah 
bergantian, hal ini berupa ada yang masuk di hari ganjil dan ada yang masuk di hari genap dan juga harus menggunakan protokol kesehatan. Hal ini dinilai efektif untuk bisa membuat situasi belajar dan mengajar kembali bisa terjadi walaupun masih terdapat kekurangan di dalamnya.

Melihat dari situasi pendidikan yang belum stabil akibat pandemi tentunya menjadi tantangan Dinas Pendidikan dan orang tua. Disinilah peranan mahasiswa dalam tri dharma mahasiswa yang terakhir tentang pengabdian dimana para mahasiswa dapat menyalurkan ilmunya atau setidaknya membantu mengajar di sekitaran dusun untuk anak-anak sekolah SD dan SMP bisa belajar dengan di bimbing oleh para mahasiswa supaya anakanak tersebut memahami materi pembelajarannya. Dalam melihat konsep pendidikan yang terganggu oleh suasana pandemi yang mengharuskan murid belajar dirumah, seharunya mahasiswa peka bahwasanya pendidikan sedang tidak baik-baik saja. Oleh karena itu IKMABAKU harus berperan dalam mengoptimalisasi pendidikan yang ada di Batang Kuis sebab dalam melaksakan pengabdian yang dilengkapi dengan keikhlasan merupakan fitrah manusia itu sendiri karena pada dasarnya manusia itu mahluk yang suci dan baik yang dilengkapi dengan perasangka baik dan buruk dan akan mendekatka dirinya dengan kebenaran (Madjid, 1987). Dengan konsep kebaikan yang dimiliki oleh manusia sebagai fitrah yang diberikan oleh Allah maka IKMABAKU harus memberikan yang terbaik dalam pendidikan di Batang kuis.

Pendidikan tidak hanya terjadi pada usia muda, bahkan sampai usia yang terbilang tuapun pendidikan masih sedang berlangsung. Pendidikan yang menjadi sarana untuk mendapatkan ilmu pengetahuan harus terus didorong oleh cita-cita kemajuan bangsa dan juga untuk mencapai Indonesia Emas. Maka untuk mencapai tujuan tersebut konsep pendidikan yang ada di Batang Kuis harus bisa diperarui mengikuti perubahan zaman supaya pendidikan di Batang Kuis tidak tertinggal dari tempat lainnya. Dengan semangat pengabdian dan juga slogan IKMBAKU “memberikan manfaat walaupun dari hal yang kecil” untuk memajukan pendidikan di Batang Kuis maka para mahasiswa harus tetap bersatu dalam wadah ini untuk membuktikan bahwasanya mahasiswa dapat memberikan perubahan yang baik untuk kepentingan bersama tentunya harus didukung oleh pihak Dinas Pendidikan dengan menggunakan sistem pendidikan yang ada guna memperlancar terjadinya sistem pendidikan yang bagus untuk membuat generasi muda yang ada di Batang Kuis menjadi generasi yang memiliki karakter dan pintar dalam melakukan banyak hal untuk perkembangan Batang Kuis yang ikut juga menyongsong Indonesia Emas. 


\section{Model Pengembangan Pendidikan}

Pada era modern ini teknologi berkembang sangat pesat, namun hal ini harus dibarengi dengan ilmu pengetahuan juga supaya terjadi persetaraan untuk bisa mencapai kemajuan baik dalam tingkat pribadi maupun daerah. Dalam model pegembangan pendidikan harus bisa menerapkan kemajuan dalam setiap sektor pendidikan baik tingkat dasar maupun menengah untuk bisa mencapai tujuan daripada pembelajaran yaitu dapa menentukan komposisi belajar dan mengajar yang sesuai dengan perkembangan zaman dan membuat suasana belajar mengajar menjadi nyaman dan aktif antara siswa dan guru.

IKMABAKU juga tentunya bisa mengembangkan pendidikan yang ada di Batang Kuis dengan cara menganalisis pembelajaran yaitu menentukan langkah-langkah persuasif pembelajaran seperti siswa yang mempunyai keterampilan supaya dapat mengimpelemtasikan apa yang bisa dilakukannya dan tentunya bermanfaat. Selain itu IKMABAKU dapat melakukan observasi mengenai sikap dasar dan pegetahuan siswa supaya bisa mendapatkan pengembangan yang sesuai dengan minat bakat yang dimiliki oleh siwa, hal ini bertujuan untuk membuat para siswa menjadi terampil dan bisa bereksplorasi di luar sekolah dengan di dampingin oleh kakak-kakak di IKMABAKU.

Strategi dalam pembelajaran yang fokus kepada minat dan bakat tentunya akan menekankan pada komponen para siswa mulai dari keahlian yang akan disesuaikan dengan jam pembelajaran supaya tidak terganggu. Selain tentang pengembangan harus ada karakteristik yang harus dibangun dikalangan siswa yang tentunya akan membuat para siswa dapat belajar dengan giat guna mengikuti arus teknologi, maka siswa harus bisa aktif dalam mencari informasi tentang suatu perkembangan yang tentunya akan bermanfaat kepada pemanfaatan sumber daya yang dimiliki guna menyonsong pembelajaran yang lebih baik supaya tidak terlihat membosankan dan akan membuat para siswa dapat menikmati suasa belajar didalam kelas tetapi diluar kelas dapat mengasah keahliannya dan bisa menempah karakternya menjadi lebih baik lagi.

\section{Motivasi Belajar}

Motivasi dapat menjadi kekuatan yang tersembunyi dalam diri manusia yang akan merangsang semangat untuk bisa melakukan suatu hal yang ingin dilakukan dengan cara yang khas. Motivasi juga bisa menjadi suatu perubahan yang ditandai dengan munculnya ide baru untuk membuat suatu kerjaan mempunyai keunikan atau cara lain yang lebih efisein termasuk halnya dalam pembelajaran. Siswa harus bisa memiliki motivasi yang lebih untuk 
meningkatkan semangat belajar demi menggapai hasil yang baik selama pembelajaran berlangsung.

Manusia punya keingin untuk tahu, sehingga tahu bukanlah suatu alat yang dibawa sejak lahir, malainkan suatu tindakan budi fikiran yang akan menghasilkan pengetahuan. Pendidikan ialah sarana untuk mendapatkan pengetahuan dan akan merambah keingin tahuaannya agar sampai kepada tujuan yang benar (Sukiman, 2017). Dengan mengedepankan pentingnya pendidikan tentunta akan membuat para siswa bersemangat untuk tetap belajar. IKMABAKU selaku pendukung tujuan pendidikan selalu memberikan motivasi kepada para siswa untuk selalu giat belajar dan tetap mengedepankan moralitas untuk tercapainya tujuan pendidikan. Sebagai generasi penerus bangsa mahasiswa harus memberikan suatu doktrin yang baik tentunya untuk dibawah, karena dengan suatu kesuksesan generasi yang ada diatas tentuny akan membuat generasi yang dibawah semangat dalam menjalankan suatu perbuatan yang baik untuk bisa mencapai Batang Kuis yang lebih jaya lagi kedepannya, karena dengan melihat anak muda di Batang Kuis yang masih mementingkan diri sendiri dan kurangnya memberikan arah yang baik kepada generasi dibawahnya, maka mahasiswa harus bisa tetap selalu memberikan doktrin yang baik untuk generasi dibawahnya. Jika demikian perkembangan pemikiran dan pemahaman masyarakat Batang Kuis tentang pentingnya pendidikan akan makin mantap, dan banyak nanti mahasiswa yang berasal dari Batang Kuis yang tujuannya memajukan Batang Kuis.

\section{Hasil Pembelajaran Untuk Dikembangkan Oleh IKMABAKU}

Tujuan umum dari belajar ialah untuk mendapatkan ilmu yang nantinya akan bermanfaat di kehidupan yang sedang dijalani atau yang akan datang. Tentunya setiap siswa mendapatkan pembelajaran yang sama disekolahnya maka notabene ilmu yang didapatkan juga pastinya sama, namun di balik kesamaan itu terdapat sesuatu yang harus di tingkatkan oleh individu siswa itu sendiri guna memiliki kepribadian yang unggul untuk bisa bersaing dengan teman-temannya dalam segi pembelajaran.

IKMABAKU yang memberikan motivasi siswa untuk terus belajar juga memberikan wejangan tentang prestasi yang harus dimiliki, hal ini tentunya di anggap biasa saja padahal, prestasi ini didalamnya penuh dengan pengalaman sebab pengalaman ialah guru paling berharga dalam hidup. Apa yang di dapatkan oleh siswa di bangku sekolah haruslah dimanfaatkan. IKMABAKU yang mempunyai bidang Pemberdayaan Sumber Daya Masyarakat (PSDM) juga mempunyai tugas untuk menumbuhkan minat dan bakat siswa yang ada di Batang Kuis. Dengan hasil pembelajaran yang di dapatkan siswa kakakkakak yang ada di PSDM mengelola dan melihat apa saja kemampuan yang 
dimiliki oleh para siswa dan di saring untuk bisa mengelompokan minat dan bakat apa saja yang dimiliki siswa tersebut yang nantinya akan di kembangkan, dan jika bisa di perlombakan untuk mendapatkan prestasi.

Dengan mengelola hasil pembelajaran oleh para siswa dengan mengkelompokkan minta dan bakat yang dimiliki oleh siswa tentunya akan berdampak kepada semangat belajar para siswa dan juga menumbuhkan semangat untuk bisa menggapai prestasi baik dalam sekolah maupun di luar sekolah. IKMABAKU konsisten untuk mengembagkan potensi yang dimiliki oleh siswa yang ada di Batang Kuis tentunya untuk memajukan pendidikan dan memperkenalkan para siswa Batang Kuis kepada daerah lain dan tentunya siap berkompetisi dengan daerah lain untuk menunjukkan kapasital dan kabiltas pendidikan Batang Kuis yang lebih baik serta dengan harapan dapat di contoh oleh daerah lain untuk tentunya kemajuan bangsa lewat sektor pendidikan.

\section{Perjuangan Pendidikan}

Ikatan Mahasiswa Kecamatan Batang Kuis yakin bahwa pendidikan di Batang Kuis akan maju dan bersifat spontas menuju pendidikan yang bermartabat dalam perkembangan zaman. Hal ini dikarenakan arah peruibahan zaman dalam kehidupan akan semakin meluas, dan pendidikan juga harus bisa terus berkembangan dan bagusnya pendidika akan menciptakan generasi yang gemilang untuk kemajuan bangsa dan kesempurnaan yang berarti bisa menanggulangi segala hambatan-hambatan dalam setiap langkah pendidikan dimana IKMABAKU dapat berperan untuk bisa menghalau hambatan-hambatan tersebut dan menunjukkan kulaitas yang bagus dari pendidikan Batang Kuis melalui prestasi dan minat bakat.

Manusia mampu berkembang terus menerus dan mampu menghancurkan lalu membangun kembali suatu apa yang telah di buat hal ini di karenakan nafasu dan ego manusia yang masih tinggi. Manusia yang mempunyai kebebasan intektual akan menjadi kekuatan terbesar untuk menghalangi para pengacau dan akan berbuat baik dalam kemenangannya untuk kebaikan bersama (Goldman, 2017).

Dengan semangat memberikan yan terbaik IKMABAKU terus melakukan inovasinya dalam memperjuangkan pendidikan yang di mulai dari hal yang sederhana, pendidikan merupakan aset penting dari generasi muda harus harus tetap di kembangkan dan tentunya mengikuti perkembangan zaman supaya pendidikan tidak tetinggal dan masyarakat dan bersaing di era global dan menciptakan perubahan yang baik untuk bangsa dan negara demi mewujudkan Indonesia emas yang akan menaikkan eskistensi Indonesia di kanca Internasional. 
Journal Continuous Education

Volume 2, Issue 2, July 2021

Page 36-45

\section{Membangun Semangat Belajar}

Dalam pendidikan satu faktor pendukungnya ialah semangat belajar yang harus dimiliki oleh para siswa untuk bisa belajar dengan giat guna mensukseskan pendidikan sesuai dengan tujuan dari pendidikan. Dengan semangat belajar yang di dorong dengan pengetahuan agama bahwasanya dalam agama pendidikan juga penting untuk bisa bertaqwa kepada Tuhan karena dengan semangat belajar dan keikhlasan akan mengahantarkan kepada peningkatan pendidikan dan akan menambah kecakapan dan kejeniusan para siswa. IKMBAKU tetap mendorong para siswa agar bisa terus semangat belajar dan bisa menjadi orang yang sukses dan bisa mensukseskan pendidikan, IKMBAKU juga turut serta dalam memberikan pemahaman tentang pentingnya pendidikan yang harus diberikan kepada para siswa, bukan hanya para siswa termasuk mereka yang putus sekolah karena setiap warga negara haruslah mendapatkan pendidikan. Jika tidak bisa mendapatkan pendidikan di dalam kelas, maka pendidikan itu juga harus diberikan di luar kelas supaya terjadinya kesatuan yang juga tercantum pada sila ke tiga pancasila.

Dengan semangat pendidikan agar terdorong para siswa untuk meningkatkan semangat belajarnya untuk bisa berkarakter dan tentunya berperestasi dan akan membanggakan orang tuanya dengan segenap kemampuan yang dimiliknya dari hasil belajar giat. Pendidikan yang berkarakter dan memmpunyai tujuan yang bagus serta di dorong oleh orangorang yang semanagat dalam meningkatkan kualitas pendidikan tentunya akan menambah semangat para siswa untuk terus berinovasi dengan melihat suatu contoh dari kakak-kakak mahasiswanya (Rohman, 2014). Setiap orang yang berusaha akan mendapatkan kesuksesan, sama seperti orang-orang yang giat belajar maka dia akan mendapatkan kesuksesakan dari upaya yang di lakukannya untuk kemajuan bangsa.

\section{Pemanfaatan Teknologi Untuk Pendidikan}

Teknologi semakin hari semakin berkembang dan memudahkan orang untuk melakukan banyak hal, teknologi juga tentunya juga berpihak kepada pendidikan dimana banyak akses belajar yang bisa di dapatkan di internet dan belakangan ini lagi maraknya perpustakaan online. IKMABAKU dalam meningkatkan pendidikan yang ada di Batang Kuis tentunya menggunakan kegiatan yang berdampingan dengan pemanfaatan teknologi yaitu, membuat Lapak Literasi. Lapak Literasi ini merupakan tempat pengembangan karalter anak yang di asah melalui kegiatan-kegiatan yang menunjang kemampuan siswa-siswa, dan yang paling menarik IKMABAKU dalam memberikan pelajaran ataupun buku tida menggunakan buku-buku seperti buku fisik, malinkan menggunakan aplikasi perpustakaan online seperti iBI Library dan 
iPusnas.

Alasan IKMABAKU menggunakan aplikasi perpustakaan online ini tentunya untuk menunjukkan kepada siswa bahwasanya handpone bukan hanya digunakan untuk bermain game, malainkan bisa digunakan untuk belajar dan bahkan bisa digunakan untuk membaca buku untuk menambah pengetahuan yang lebih lebih luas lagi. Dengan pemanfaatan teknologi di barengi dengan pelatihan-pelatihan untuk bisa menunjang kebutuhan siswa akan pendidikan dan minat bakat yang dimiliki tentunya harus di kembangkan di Lapak Literasi untuk membuat generasi yang berada di Batang Kuis mampu menjadi lebih baik dan bisa bersaing di luar daerah.

Digitalisasi yang di buat oleh IKMABAKU tentunya akan mengubah stigma bahwasanya handphone untuk anak-anak kebanyakan haya akan digunakan untuk bermain game, padahal bisa digunakan untuk belajar dan membaca buku dengan muda melalui aplikasi perpustakaan secara online. Dengan mengedepankan pendidikan tentunnya hal ini akan membantu terjadinya peningkatan pendidikan yang efisien.

\section{KESIMPULAN}

Dengan mengedepankan pendidikan tentunya akan membuat potensi kreatif suatu daerah akan menjadi lebih maju dan akan membuat banyak prestasi baru terhadap siswa yang ada di Batang Kuis. Dengan perkembangan pendidikan juga harus bisa meratakan pendidikan untuk bisa berkesimbangan pendidikan yang membuat keadilan sosial dimana satu di antara keadilan itu ialah keadilan dalam bentuk pendidikan. Dengan menggunakan lapak literasi dengan mengedanpakan pembelajaran berbasis teknologi tentunya akan memberikan pemahaman kepada siswa bahwasanya handphone bisa juga digunakan untuk belajar, dan pembelajarannya juga mudah karena tersedia materi yang mudah di akses dan perpustakaan yang online mudah di baca juga. Mahasiswa harus turut andil dalam perkembangan pendidikan, jangan terlalu apatis mengenai pendidikan yang ada di daerah tempat tinggal karena Indonesia kaya akan ilmu pengetahuan. Jadi sebagai generasi muda haruslah tetap belajar dan berusaha sebaik mungkin untuk bisa mendapatkan kesuksesan, maka pendidikan ialah gerbang daripada kesuksesan itu sendiri. Menempah karakter dan juga mengembangkan minat dan bakat juga bisa di lakukan oleh pendidikan, tujuan dari memajukan pendidikan yang ada di Batang Kuis ini ialah utuk bisa menunjukkan kreatifitas yang dimiliki oleh siswa yang akan mempunyai daya saing yang tinggi dan berpeluang memajukan Batang Kuis. 
Journal Continuous Education

Volume 2, Issue 2, July 2021

Page 36-45

\section{DAFTAR PUSTAKA}

Copleston, F., \& Plato. (2020). Basa-Basi.

Darwamawan, D. (2013). Metode Penelitian Kuantitatif. Rosdakarya.

Goldman, E. (2017). Anarkisme Apa Yang Sesungguhnya Diperjuangkan. Jalan Baru.

Madjid, N. (1987). Islam Kemodernan dan Keindonesiaan. Mizan.

Rohman, A. (2014). Kebijakan Pendidikan. Aswaja Pressindo.

Sugiyono. (2016). Metode Penelilitian Kuantitatif, Kualitatif dan RED. Alfabeta.

Sukiman. (2017). Teologi Pembanhunan Islam. Perdana Publishing.

Zaini, M. F., \& Syafaruddin, S. (2020). The Leadership Behavior of Madrasah Principals in Improving the Quality of Education in MAN 3 Medan. Jurnal Iqra': Kajian Ilmu Pendidikan, 5(2), 95-106. https://doi.org/10.25217/ji.v5i2.649 